\title{
СОЦІАЛЬНО-ЕКОНОМІЧНА ДОЦІЛЬНІСТЬ УПРАВЛІННЯ ФІНАНСОВО-ВИРОБНИЧИМИ СИСТЕМАМИ
}

\author{
DOI: 10.32620/cher.2019.2.03
}

\begin{abstract}
Постановка проблеми. У статті приводиться авторське думка щодо розробки критеріїв доцільності управління фінансово-економічними процесами в країні. Проводяться паралелі між корисністю та користю управління фінансово-виробничими системами. Метою статті є обгрунтування соціально-економічної доцільності управління фінансово-виробничими системами через використання коефіцієнта соціально корисної дії виробничої системи та відображення корисності як принципу пріоритетності на рівні формальної констатації факту наявності ефективності або можливого розміру заподіяного економічного збитку. Об'єктом дослідження виступає - фінансово-виробничі системи з точки зору їхньої можливості формування соціальної корисності різних рівнів ії використання. Методи, використані в дослідженні: системний підхід, метод узагальнення, порівняння, логічно-змістовний метод, монографічний метод, методи індукції та дідукції тощо. Основною гіпотезою є те, прибутковість функціонуючого підприємства залежить від варіанту економічної політики, яка формується за рахунок економічної структури і соціальної корисності сфери його виробництва, тобто його економічного коефіцієнта корисної дії. Виклад основного матеріалу. Соціальна корисність обгрунтовується як ключовий показник, на який потрібно орієнтуватися в прийнятті управлінських рішень в сфері економіки і фінансів. гомеостаз не виконує функцію оптимізації виробничої системи, а лише врівноважує співвідношення зменшення та компенсації вартості в даній системі. В результаті досягається безперервність виробництва, тобто завжди виконуються умови за наявністю позитивної вартості в кожному виробничому елементі при певному рівні невиробничого споживання вартості робочої силою. Оригінальність та практичне значення дослідження полягає у розробці схеми управління виробничою системою з урахуванням соціальної корисності, а також математичної інтерпретації системності і гомеостазу виробничої системи. У висновках дослідження обгрунтовано, економічні показники виробничої системи можуть використовуватися тільки для оперативної оцінки результатів діяльності, але не можуть стати базисом прогнозування соціальної результативності діяльності фінансово-виробничої системи.
\end{abstract}

Ключові слова:

соціальна корисність, суспільна доцільність, економічна ефективність, управління виробничими системами .

\section{SOCIO-ECONOMIC FEASIBILITY OF FINANCIAL AND PRODUCTION SYSTEMS MANAGEMENT}

Formulation of the problem. The author's opinion on developing criteria of expediency of management of financial and economic processes in the country is given in the article. There are parallels between the usefulness and benefits of managing financial and production systems. The purpose of the article is to justify the socioeconomic feasibility of managing financial and production systems through the use of the socially useful factor of the production system and the display of utility as a principle of priority at the level of formal statement of the fact of the availability of the effectiveness or possible size of the economic loss. The object of the study is financial-production systems in terms of their ability to form social utility. Methods used in the research are a systematic approach, a method of generalization, comparison, logical-content method, monographic method, methods of induction and deduction. The hypothesis of research the profitability of a functioning company depends on the variant of economic policy, which is formed at the expense of the economic structure and social utility of its sphere of production, that is, its economic efficiency. The statement of basic materials. Social utility is justified as a key indicator to be guided by in making manage-

${ }^{1}$ Ліхоносова Ганна Сергіївна, д-р екон. наук, доцент кафедри «Фінанси», Національний аерокосмічний університет ім. М. Є. Жуковського «Харківський авіаційний інститут», м. Харків, Україна.

Likhonosova Ganna, Doctor of Economis Sciences, Associate of Professor of Finance Department National Aerospace University «Kharkiv Aviation Institute», Kharkiv, Ukraine.

ORCID ID: 0000-0001-6552-8920

e-mail: a.likhonosova@gmail.com 
rial decisions in the field of economics and finance. Homeostasis does not perform the function of optimizing the production system, but only balances the ratio of reduction and compensation of value in this system. As a result, the continuity of production is achieved, that is, the conditions are always satisfied at the presence of positive value in each production element at a certain level of non-productive consumption of labor costs. Originality and practical significance of the research is to develop a scheme for managing the production system, taking into account social utility, as well as mathematical interpretation of the systemic and homeostasis of the production system. Conclusions of research are reasonable, economic indicators of the production system can be used only for the operational evaluation of performance, but cannot be the basis for predicting the social performance of the financial and production system.

Key words :

social utility, social expediency, economic efficiency, management of production systems.

\section{СОЦИАЛЬНО-ЭКОНОМИЧЕСКАЯ ЦЕЛЕСООБРАЗНОСТЬ УПРАВЛЕНИЯ ФИНАНСОВО-ПРОИЗВОДСТВЕННЫМИ СИСТЕМАМИ}

Постановка проблемы. В статье приводится авторское мнение по разработке критериев целесообразности управления финансово-экономическими процессами в стране. Проводятся параллели между полезностью и пользой управления финансово-производственными системами. Целью статьи является обоснование социально-экономической целесообразности управления финансовопроизводственными системами через использование коэффициента социально полезного действия производственной системы и отображения полезности как принципа приоритетности на уровне формальной констатации факта наличия эффективности или возможного размера причиненного экономического ущерба. Объект исследования - финансово-производственные системы с точки зрения их возможности формирования социальной полезности. Meтоды, использованные в исследовании: системный подход, метод обощения, сравнения, логически-содержательный метод, системный подход, монографический метод, методы инду-кции и дидукции тому подобное. Гипотеза исследования - доходность функционирующего предприятия зависит от варианта экономической политики, которая формируется за счет экономической структуры и социальной полезности сферы его производства, то есть его экономического коэффициента полезного действия. Изложение основного материала. Социальная полезность обосновывается как ключевой показатель, на который нужно ориентироваться в принятии управленческих решений в сфере экономики и финансов. гомеостаз не выполняет функцию оптимизации производственной системы, а лишь уравновешивает соотношение уменьшения и компенсации стоимости в данной системе. В результате достигается непрерывность производства, то есть всегда выполняются условия по наличию положительной стоимости в каждом производственном элементе при определенном уровне непроизводственного потребления стоимости рабочей силой. Оригинальность и практическое значение исследования заключается разработке схемы управления производственной системой с учетом социальной полезности, а также математической интерпретации системности и гомеостаза производственной системы. В выводах обоснованно, экономические показатели производственной системы могут использоваться только для оперативной оценки результатов деятельности, но не могут стать базисом прогнозирования социальной результативности деятельности финансово-производственной системы.

\section{Ключевые слова:}

социальная полезность, общественная целесообразность, экономическая эффективность, управление производственными системами.

Постановка проблеми. Саме спрямованість фінансово-економічних процесів відображає стан економічної стабільності і безпеки держави, а також є дзеркальним відображенням соціальної політики, що проводиться урядом країни, соціальної спрямованості та доцільності його економічного підгрунтя. Кожна людина, живучи в соціумі, виконує ту чи іншу суспільно значиму роль, тобто несе на собі певну соціальну корисність, безкорисність або марність. Так само й виробнича система, може бути життєздатною і дієздатною, однак, малокорисною для суспільства і конкретного споживача. Багато в чому, це відображає сучасну виробничу систему України і можливості їі фінансово-економічного забезпечення.

2018 рік для України був роком очікування. Країна чекала грошей Міжнародного валютного фонду [1], до того певним чином фінансово на країні відобразился початок виборчої кампанії. Теперішній 2019 рік не зменшує внутрішні ризики для країни. За 
даними Національного банку, Україні доведеться погасити понад 5,8 млрд.дол. своїх зовнішніх боргів [2]. Ця сума $є$ еквівалентом третини валютних резервів країни на кінець 2018 року. Видача єврооблігацій у жовтні може допомогти Україні покрити принаймні половину необхідної суми, проте гривня знову втратить в ціні. Це не матиме катастрофічних наслідків, але відчуватиме падіння національної валюти кожен громадян [3, с. 23].

Саме в ситуації фінансовоекономічної непрогнозованності та нестабільності керівництво країни має приділити увагу креативним імпульсам інтенсифікації національної економіки. Одним 3 таких факторів зі зворотньою дією є корисність фінансового оснащення виробних систем країни. Корисність - це здатність блага, товару або послуги задовольняти яку-небудь людську потребу [4, с. 582]. У зв'язку з тим, що в соціально-економічній системі практично всі результати носять суб'єктивний, соціально відчутний характер, доцільно використовувати показники управління фінансовоекономічними процесами не на локальному рівні, а 3 точки зору саме соціальноекономічної ефективності. Одним з критеріїв соціально-економічної ефективності $\epsilon$ соціальна корисність, яка здатна відобразати соціальну та економічну користь.

Аналіз останніх досліджень та публікацій. Соціальну корисність найчастіше розглядають 3 точки зору доцільності соціального підприємництва [4, с. 57-61]. 3 точки зору державного забезпечення попри за- гальну своєчасність і необхідність соціальних реформ з ними пов'язаний ряд ризиків, які наразі майже не прораховані. Наприклад, починаючи з 2020-го соціально незахищених людей щороку ставатиме приблизно на 100 тис. більше [5]. Авторські дослідження вже були спрямовані на пошук нестантарних рішень щодо пожвавлення соціально-економічного залучення та усунення проявів відторгнення на всіх стадіях виробничого процесу [6, с. 93-107] та різних рівнях управління [7, с. 135-146].

Виходячи 3 вищенаведеного, метою статті $€$ обгрунтування соціальноекономічної доцільності управління фінансово-виробничими системами через використання коефіцієнта соціально корисної дії виробничої системи та відображення корисності як принципу пріоритетності на рівні формальної констатації факту наявності ефективності або можливого розміру заподіяного економічного збитку.

Виклад основного матеріалу дослідження. Соціальна користь, як критерій соціально-економічної ефективності, $є$ показником завжди умовним, суб'єктивним і виражається через універсальні вартісні елементи [8]. Соціальна користь результатів людської діяльності проявляється тільки на стадії їхнього споживання, тому розмір доходу або прибутку, отриманий на стадії виробництва або реалізації продукції, не може свідчити про економічну ефективність, а тим більше про соціальну корисність відповідних результатів (рис. 1).

Показники управління

соціально-економічними процесами

Здатність блага задовольняти потребу

Рис. 1. Схематичне відображення трансформації корисності соціально-економічних процесів Джерело: розроблено автором 
У зв'язку з неможливістю кількісно оцінити соціальну корисність, їі можна виразити як принцип пріоритетності або порівняльної відносності на рівні формальної констатації самого факту наявності ефективності або через показники можливого розміру предотвращенного економічного збитку (рис. 2).

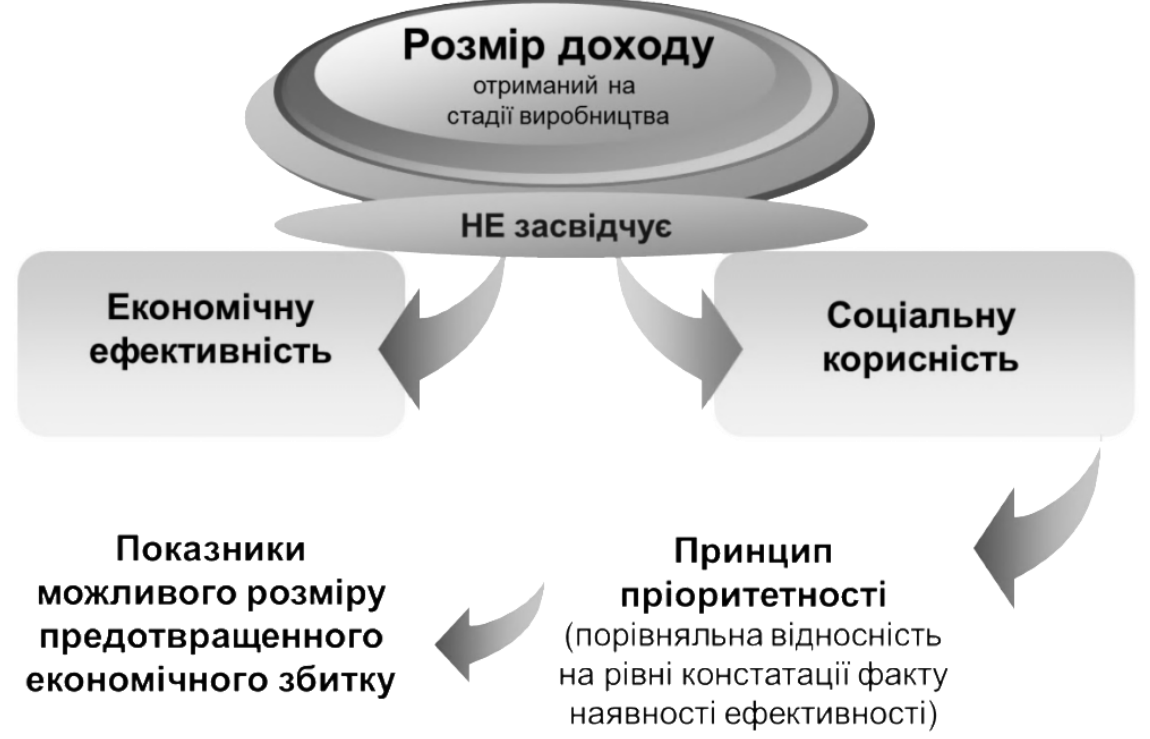

Рис. 2. Варіативність кількісного оцінювання соціальної корисності Джерело: розроблено автором

Корисність виробничої системи визначається здатністю виконувати призначену нею функцію - задовольняти матеріальні потреби всіх споживачів. Отже, корисність виробничої системи повинна визначатися співвідношенням того, що безпосередньо споживається соціумом і того, що проводитися виробничою системою.

Забезпечення сталого розвитку економіки на будь-яких рівнях іiі формування та реалізації - це, перш за все, системне управління фінансовими потоками. Для цього необхідні повноваження, можливості, фінансові та матеріальні кошти, якими можуть розпоряджатися органи управління на різних рівнях. У рішенні задач управління економікою країни беруть участь всі іï людські, матеріальні та фінансові ресурси незалежно від форм власності володіння конкретним майном. Всі ресурси країни, що знаходяться в розпорядженні державних органів, складають соціально-економічний базис управління, в який входять (рис. 3):

1) матеріальні ресурси, включаючи частину коштів виробництва та ті природні ресурси, які є державною власністю;

2) фінансові ресурси, розпорядження якими знаходиться у виключній компетенції держав;

3) ресурси непрямого розпорядження приватним і кооперативним майном внаслідок використання законодавчих і організаційно-технічних механізмів в області економіки, фінансів і торгівлі.

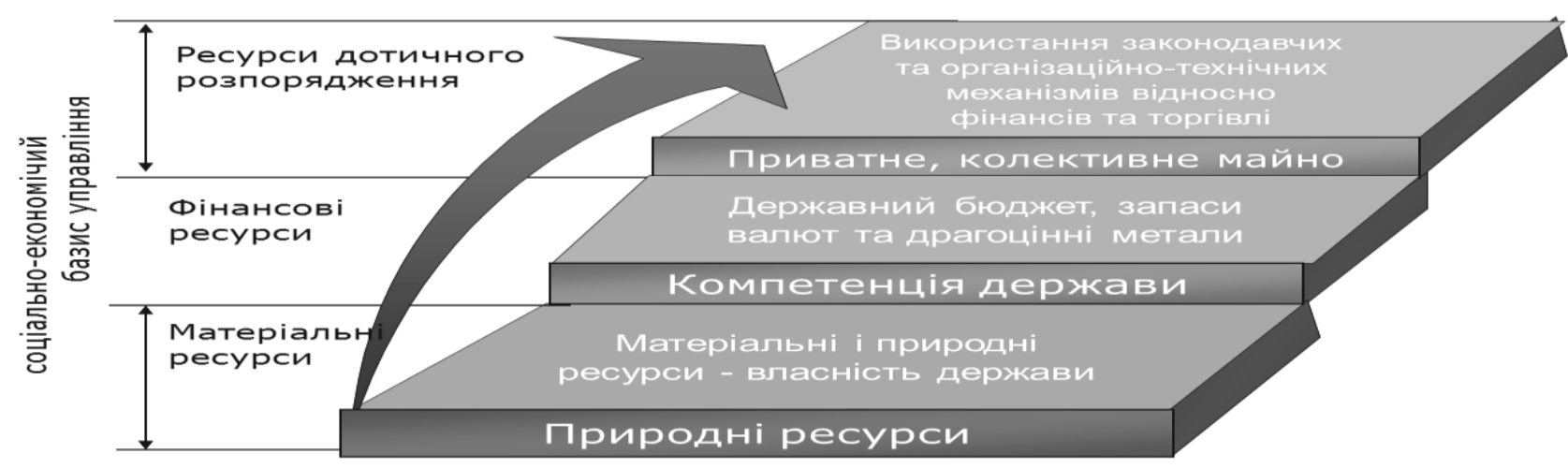

Рис. 3. Системність управління економіко-фінансовими процесами Джерело: розроблено автором 
Рішення одних завдань вимагає прямого безпосереднього розпорядження фінансовими і матеріальними ресурсами. Це забезпечення державних соціальних гарантій пасивним учасникам виробництва (пенсіонерам, безробітним, студентам, інвалідам, дітям), утримання державного апарату, армії і служб безпеки.

На макрорівні управління економікою передбачає забезпечення організаційно-економічних трансформацій [6, с. 93107]: злиття різних видів вартості і споживчої вартості в масштабі регіонів, країни і групи країн; взаємодія кругообігу виробничих елементів 3 кругообігом речовин в природі; взаємодія виробничих систем в масштабі регіонів, країн і груп країн.
Управління будь-яким процесом здійснюється шляхом впливу на нього 3 метою зміни ходу процесу в потрібному напрямку. Зміна ходу процесу, наприклад, зміна його напрямку, прискорення або уповільнення, вимагає витрат енергії, поперше, на приведення в дію механізмів управління, по-друге, на зміну параметрів динаміки самого процесу. У більшості випадків інші витрати набагато перевищують перші, але зміна динаміки процесу можливо як за рахунок зовнішнього підведення енергії, так і за рахунок його внутрішньої енергії (рис. 4).

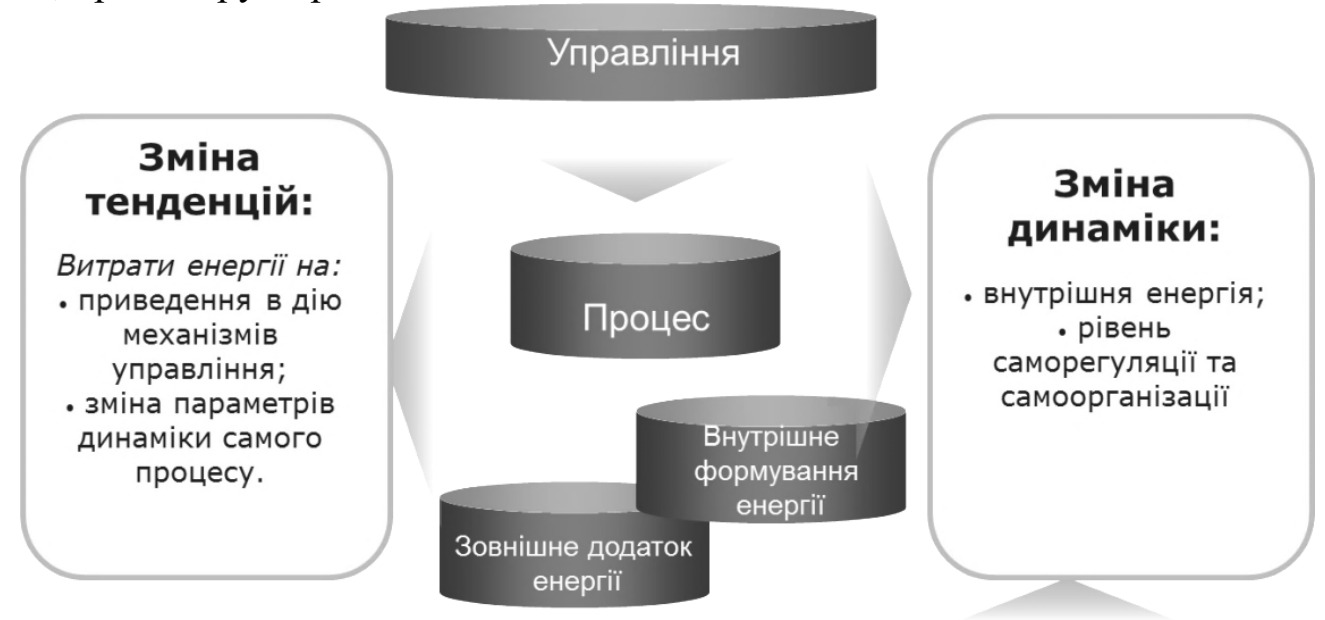

\section{Відносно фінансово-економічних процесів}

Рис. 4. Енергетичні витрати процесу управління Джерело: розроблено автором

Стосовно фінансово-економічних процесів, управління повинно зводитися до такого впливу, щоб ii динаміка змінювалася, притому в потрібному напрямку, перш за все, за рахунок внутрішньої енергії на рівні саморегуляції і самоорганізації. Енергетичним базисом в економічній системі $\epsilon$ праця людини та маса уречевленої праці, що міститься в виробничих елементах - робочій силі, засобах і предметах праці. Це вартість, яка додатково створюється працею. При цьому іiі створення формується на рівні суб'єктів господарювання, де економічні процеси протікають за рахунок внутрішньої вартісної «енергії» - за рахунок коштів, які акумулюються підприємствами
[9, с. 16-22], об'єднаннями, галузями.

3 процесів мікрорівня щодо створення i перетворення енергетичного базису (вартості) утворюються процеси макрорівня по злиттю різних видів вартості в загальні потоки кругообігу виробничих елементів системи в цілому. Однак, це процеси взаємозалежні один від одного. Від того, в якому напрямку і з якою динамікою будуть здійснюватися процеси на рівні держави, будуть залежати процеси створення вартості i ii перетворення в прибуток на рівні підприємств.

Прибутковість будь-якого підприємства істотно залежить від варіанту економічної політики, яка формується за рахунок 
економічної структури і соціальної корисності його виробництва, тобто його економічного коефіцієнта корисної дії, який відображений в показнику (1).

$$
\begin{aligned}
& X_{b}=\frac{A_{b}}{A}, A_{b}=A_{1}+A_{2}+A_{3}, \\
& A=\sum_{k=1}^{3} \sum_{l=1}^{3} A_{k l}, k, l=1,2,3,
\end{aligned}
$$

где $\mathrm{A}_{1}, \mathrm{~A}_{2}, \mathrm{~A}_{3}$ - величина вартості відповідно робочої сили, засобів праці та предмета праці в сфері відтворення робочої сили; $\mathrm{A}_{\mathrm{kl}}$ - величина вартості виробничих елементів в сферах відтворення.

Наприклад, в варіантах переважання у виробництві вагомості саме коштів праці, більш імовірна низька соціальна корисність виробництва. А це веде до низького рівня заробітної плати, зменшення додаткової праці, скорочення внутрішнього ринку i, як наслідок, падіння прибутковості підприємств.

Щоб загальні потоки вартості в процесах кругообігу виробничих елементів не були стихійними, а протікали в потрібному напрямку і 3 потрібною динамікою, ними необхідно системно управляти. Для цього потрібно розробити механізми управління. Як на рівні підприємства, так і на рівні держави відповідно до функцій і способами державного управління існують певні механізми і відповідні інструменти управління: 1) законодавчі механізми, які формуються нормами законів, актів, принципів, правил поведінки фізичних і юридичних осіб; 2) фінансово-економічні механізми, що утворюються фінансовим і економічним впливом органів управління на фінансовоекономічні процеси; 3) організаційнотехнічні механізми, утворені державними органами адміністративного та технічного управління суспільним виробництвом.

Органічне поєднання в потрібних пропорціях даних механізмів дозволяє створити ефективну систему управління суспільним виробництвом на кожному етапі його розвитку.

Виходячи 3 призначення суспільного виробництва, управління фінансовоекономічними процесами на рівні держави має виконати три економічні завдання:

1) підтримувати високу прибутковість всіх або більшої частини виробничих підрозділів (підприємств, фірм, об'єднань, галузей), щоб забезпечувалася життєздатність виробничої системи в цілому;

2) підтримувати матеріально- фінансову збалансованість господарства, щоб виробництво було дієздатним і функціонувало без економічних криз і екологічних катастроф;

3) підтримувати досить високою соціальну корисність виробництва, тобто його економічний коефіцієнт корисної дії, щоб життєвий рівень людей відповідав рівню розвитку виробництва.

Соціальна корисність виробництва визначається виробництвом і споживанням продуктів і послуг населенням, що залежить не тільки від величини використовуваних виробничих елементів, але і від їх співвідношення, тобто від економічної структури виробництва. Тому соціальна корисність суспільного виробництва характеризується, перш за все, часткою $\left(\mathrm{X}_{\mathrm{b}}\right)$ тієї частки виробничих елементів, яка задіяла у відтровенні робочої сили (2):

$\boldsymbol{X}_{\boldsymbol{b}}=\frac{A_{b}}{\boldsymbol{A}}=\mathbf{1}-\boldsymbol{X}_{\boldsymbol{A}}\left(\boldsymbol{A}_{\boldsymbol{b}}=\boldsymbol{A}_{\mathrm{pc}}+\boldsymbol{A}_{\mathrm{cт}}+\boldsymbol{A}_{\text {пт }}\right)$, звідки

$$
X_{A}=\frac{A-A_{b}}{A}=1-X_{b} .
$$

Пов'язаний показник $\boldsymbol{X}_{\boldsymbol{A}}$ визначає частку виробничих елементів, що беруть участь у відтворенні засобів праці і предмета праці, і характеризує ступінь технічності виробництва. Чим він більший, тим вище озброєність праці і матеріаломісткість виробництва. Але чим більше показник $\boldsymbol{X}_{\boldsymbol{A}}$, тим менше показник $\boldsymbol{X}_{\boldsymbol{b}}$, що характеризує соціальну корисність виробництва. Показник $\boldsymbol{X}_{\boldsymbol{A}}$ за своєю сутністю визначає соціальний коефіцієнт корисної дії виробництва, який, на відміну від технічного коефіцієнта корисної дії, має тенденцію до зниження.

3 урахуванням величини показника соціальної корисності виробництва слід вирішувати задачу його матеріальнофінансової збалансованості та дієздатності. В першу чергу потрібно контролювати i забезпечувати збалансованість оплати праці, а також споживання матеріальних благ пасивною частиною населення - пенсіонерами, учнями, дітьми. Механізми саморегуляції i самоорганізації більше сприяють стримуванню, ніж стимуляції невиробничого споживання. Це може, по-перше, знижувати соціальну корисність i, по-друге, порушувати матеріально-фінансову збалансованість виробництва і навіть приводити до економічних криз.

Для підтримки стабільності виробництва і споживання необхідно, щоб плато- 
спроможність населення відповідала вибраному варіанту економічної політики. 3 іншого боку, зайва платоспроможність населення, тобто зайве накопичення грошей населенням призводить або до інфляції, або до дефіциту товарів, якщо ціни на них незмінні. Останне було особливо характерно для соціалістичних країн, так як їхні уряди намагалися утримувати досить високий рівень заробітної плати без розширення можливості і потреби для її витрачання.

Рівнем споживання матеріальних благ, платоспроможністю населення та інфляцією слід системно управляти. Показником, який характеризує підсумковий результат цих процесів управління буде (4):

$$
\boldsymbol{n}_{b}=\boldsymbol{B}_{d} / \boldsymbol{D}_{b},
$$

де

$$
B_{d}=\sum_{i=1}^{10} B_{D i},(i=1,2, \ldots, 10),
$$

де $\boldsymbol{B}_{\boldsymbol{D} \boldsymbol{i}^{-}}$величина наявних матеріальних благ і-го виду (харчування, одяг, житло) в поточних цінах і вимагають оплати грошима; $\boldsymbol{B}_{\boldsymbol{d}}$ - поточна платоспроможність населення за вартістю грошей, які $\epsilon$ в розпорядженні населення.

Значним показників (4) і (5) повинна визначатися соціальна спрямованість і розвиток виробництва відповідно до вибраного варіанта економічної політики.

Виходячи 3 того, що виробнича система $є$ складною динамічною і відкритою системою, управління нею слід розглядати 3 позиції системності. Будь-якої складної відкритої системи притаманні системні характеристики, однією з яких є гомеостаз.

Гомеостаз це - процес, який регулює або підтримує систему в стійкому стані щодо навколишнього середовища, яка постійно змінюється і оточує цю систему [10, с. 252].

Поняття про гомеостаз, як про вбудованих механізмах регулювання життєздатності живих організмів, в тому числі і людини, було сформульовано незабаром після появи кібернетичної науки. Н. Вінер поставив питання про пошук подібних механізмів в державі i, зокрема, в економіці [11, с. 65-68]. Однак, за його твердженням, тоді економічна наука ще не була достатньо розвинена, особливо в математичному плані, щоб можна було поставити і вирішити задачу розкриття гомеостазу економіки.

Розвиток форм суспільного буття, особливо в державному устрої суспільства, було б неможливо, якби не існували і не вдосконалювалися ті внутрішні механізми, які постійно підтримують активність соціального організму на рівні його достатньої життездатності.

Вбудований в суспільне виробництво механізм економічного гомеостазу діє на основі об'єктивних законів економіки виробництва, які також залежать від поведінки конкретних людей. Сам процес праці здійснюють люди. Свою працю і виробництво вони можуть організовувати на свій власний, тобто суб'єктивному уявленню як кожного окремо індивідуума, так і суспільства в цілому.

Для суб'єктів виробничого процесу ця система надбудованих механізмів має суб'єктивно-об'єктивний характер. Люди можуть ці правила змінювати, але, після прийняття їх, зобов'язані їх виконувати. Причому змінювати правила, можливо, тільки спільноті або групі людей, а для індивідуумів вони є цілком об'єктивною реальністю. В результаті з системи надбудованих людьми механізмів утворюється зворотний зв'язок гомеостазу у вбудованих механізмах регулювання процесів відтворення.

Слід зазначити, що гомеостаз не виконує функцію оптимізації виробничої системи, а лише врівноважує співвідношення зменшення та компенсації вартості в даній системі. В результаті досягається безперервність виробництва, так що завжди виконуються умови за наявністю позитивної вартості в кожному виробничому елементі при певному рівні невиробничого споживання вартості робочої силою (рис. 4).

Такий же результат випливає 3 правил економічної динаміки [12, с. 45]. Згідно 3 правилом, яке виключає в економіці вічний двигун другого роду, вироблений продукт за своєю вартістю ніколи не може бути більше сумарної вартості виробничих елементів і додаткової праці, витраченого на його виробництво. Відповідно, будь-коли може бути перенесена вся вартість виробничих елементів, що і забезпечує безперервність виробництва. Виробництво створюється суспільством не заради самого виробництва, а для формування та примноження засобів існування [13]. 


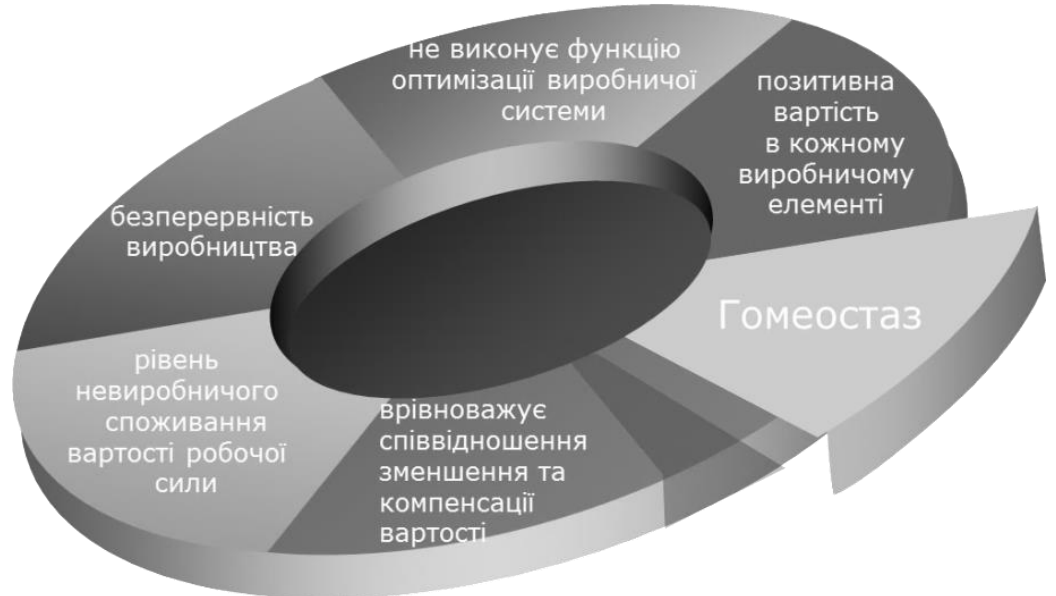

Рис. 4. Категорізація гомеостазу виробничої системи Джерело: розроблено автором

Тому спонукальним мотивом реагування на кінцевий результат виробництва $\epsilon$ величина саме невиробничого споживання частини вироблених продуктів. Ця мотивація через систему законодавчих, фінансовоекономічних та адміністративно-технічних механізмів, в кінцевому рахунку, реалізується в виконавчу дію зміни параметрів виробництва. А це, в свою чергу, змінює величину споживання матеріальних благ.

Висновки та перспективи подальших досліджень. Таким чином, гомеостаз включає в себе жорсткий механізм стабілізації виробничої системи на основі об'єктивних законів економіки виробництва і податливий механізм зворотного зв'язку суб'єктивних дій спільноти людей.

В теорії управління зворотні зв'язки механізму гомеостазу, на відміну від інших видів зворотних зв'язків, характеризуються повільністю дії. У них сигнал виконання формується в результаті не поодиноких, а багатьох розсіяних в часі подій. Аналогічно i в суспільному виробництві, де в кожну хвилину відбуваються тисячі, мільйони $\mathrm{i}$ мільярди економічних подій різного виду: покупка і продаж, підвищення і зниження цін, відсоткових ставок, звільнення і прийом на роботу, міграція робочої сили, імпорт і експорт тощо. На всі ці події миттєво реагують зворотні зв'язки окремих індивідуумів, колективів підприємств, органів управління. Зворотній зв'язок механізму гомеостазу, що утворюється у вигляді рішень законодавчих і виконавчих органів макрорівня, виробляє виконавчий сигнал у вигляді заборони і дозволу, покарання і заохочення за результатами аналізу суми подій мікро- i макрорівня за досить тривалий проміжок часу. Виконання вироблених рішень на макрорівні також вимагає більшого часу, ніж на мікрорівні. Все це призводить до того, що зворотний зв'язок механізму гомеостазу суспільного виробництва має властивість повільності.

Таким чином, соціальна корисність, як критерій соціально-економічної ефективності, проявляється тільки на стадії споживання товарів, робіт, послуг. Тому економічні показники виробничої системи можуть використовуватися тільки для оперативної оцінки результатів діяльності, але не можуть стати базисом подальшого відображення соціальної результативності діяльності виробничої системи. Проте, в умовах цивілізації, коли очікуваний результат випадає з-під контролю не тільки індивіда, але й суспільства, користь втрачає свій універсальний сенс, роль якого поступово переходить до цінності. Відповідно, подальші авторські дослідження будуть спрямовані на виявлення ціннісних орієнтирів соціально-економічної корисності та фінансового підгрунтя для цього.

\section{Література}

1. Качалова Г. Меморандум МВФ: какие обязательства взяла на себя Украина / Г. Качалова // Українська правда [Електронний ресурс]. - Режим доступу: https://www.epravda.com.ua/rus/publications/

2. Звіт про фінансову стабільність. Червень 2019 // Офіційний сайт Національного банку України [Електронний ресурс]. - Режим доступу: https://bank.gov.ua/doccatalog

3. Shavalyuk L. Slaloming the risk. Ukraine's economy will grow more resilient if it survives 2019 / L. Shavalyuk // The Ukrainian 
Week. - 2019. - № 1(131). January.- C. 23.

4. Ткачук I. Я. Соціальне підприємництво як фактор розвитку малого та середнього підприємництва в україні / I. Я. Ткачук, X.-I. В. Євчук // Агросвіт. - 2017. - № 9. - С. 57 - 61.

5. Артюшенко B. Соціальні реформи уряду - ризики чи користь? / В. Артюшенко // Джеркало тижня [Електронний ресурс]. - Режим доступу: https:// https://dt.ua/internal/socialni-reformi.html

6. Calinescu T. Estimation of conditions the realization of democratic mechanisms the transformation of society: tearing away and social dialog / T. Calinescu, G. Likhonosova, O. Zelenko // Montenegrin Journal of Economics. - 2018. Vol. 1(14). - C. 93-107.

7. Druzhynina V. Strategic imperatives ensuring population welfare with transformation exclusion conditions / V. Druzhynina, G. Likhonosova // Baltic Journal of Economic Studies. - 2017. - № 3, 5 December. - C. 135146.

8. Соловьёв В. С. Теория социальных систем: монография в 5 томах. Том 5. Улучшение в финансвой и кредитной системе / В. С. Соловьёв. - Новосибирск: СибАНС, 2006.

9. Likhonosova $G$. Synergistic justification capacity of socio-economic exclusion / G. Likhonosova // Management and education. Economic, finance, accounting. Vol. XII (1). Burgas: University «Prof. Dr Assen Zlatarov», България, 2016. - C. 16-22.

10. Великий тлумачний словник сучасної української мови / За ред. В. Бусела. - Київ, Ірпінь: «Перун», 2009. - 1732 с.

11.Wiener $N$. Individual and social homeostasis / N. Wiener // Social sciences and modernity. - 1994. - № 6. - С. 65-68.

12.Мельник Л. Г. Основы устойчивого развития: монография / Л. Г. Мельник - Суми: университетская книга, 2006.

13.Бабицкий А. Ф. Социал. Законы и теория экономических процессов настоящего и будущего : монография / А. Ф. Бабицкий. - К. : МАУП, 2005. - 495 с.

\section{References}

1. Kachalova, G. The IMF Memorandum: What Ukraine Ukraine Undertook.

Стаття надійшла
до редакції : 01.05 .2019 p.

Ukrainian Pravda. Retrieved from : https://www.epravda.com.ua/rus/publications/

2. Financial Stability Report. June 2019 // Official site of the National Bank of Ukraine. Retrieved from: https://bank.gov.ua/doccatalog

3. Shavalyuk, L. (2019). Slaloming the risk. Ukraine's economy will grow more resilient if it survives 2019. The Ukrainian Week, 1(131). January, 23.

4. Tkachuk, I. Ya \& Yevchuk, H.-I. V. (2017). Social entrepreneurship as a factor of development of small and medium entrepreneurship in Ukraine. Agrosvit, 9, 57-61.

5. Artyushenko, V. Government Social Reforms - Risks or Benefits? Mirrow of the week. Retrieved from: https://dt.ua/internal/socialnireformi-uryadu-riziki-chi-korist-254231_.html

6. Calinescu, T. \& Likhonosova, G. \& Zelenko, O. (2018). Estimation of conditions the realization of democratic mechanisms the transformation of society: tearing away and social dialog. Montenegrin Journal of Economics, 14, 1, 93-107.

7. Druzhynina, $V . \&$ Likhonosova, $G$. (2017). Strategic imperatives ensuring population welfare with transformation exclusion conditions. Baltic Journal of Economic Studies, 3,5 December, 135-146.

8. Soloviev, V. S. (2006). Theory of social systems: a monograph in 5 volumes. Volume 5. Improving the financial and credit system. Novosibirsk: SibAHS.

9. Likhonosova, G. (2016). Synergistic justification capacity of socio-economic exclusion. Management and education. Economic, finance, accounting. Vol. XII (1). Burgas: University «Prof. Dr Assen Zlatarov», България, 16-22.

10.Busel, V. (2009). Large Dictionary of Contemporary Ukrainian Language. Kyiv; Irpen: "Perun".

11.Melnyk, L. G. (2006). Fundamentals of Sustainable Development. Sumy: "University Book".

12. Wiener, N. (1994). Individual and social homeostasis. Social sciences and modernity, 6, 65-68.

13. Babitsky, A. F. (2005). Social. Laws and theory of economic processes of the present and the future. Kyiv: IAPM, 496.

\section{Стаття прийнята}

до друку: 26.06.2019 p.

Бібліографічний опис для цитування :

Ліхоносова Г. С Соціально-економічна доцільність управління фінансово-виробничими системами / Г. С. Ліхоносова // Часопис економічних реформ. - 2019. - № 2 (34). - С. 26-34. 